\title{
STRUCTURAL CHANGES IN THE DAIRY INDUSTRY AND THEIR IMPACT ON THE EFFICIENCY OF DAIRIES - A POLISH EXAMPLE
}

\author{
Maria Zuba-Ciszewska, $\mathrm{PhD}^{1}$ \\ Faculty of Social Sciences, John Paul II Catholic Univeristy of Lublin
}

\begin{abstract}
The purpose of this paper was to determine structural changes in Poland's dairy industry and assess their impact on the efficiency of dairies. It was not until the mid-nineties that the process of concentrating milk processing and the rationalization of its production began in the country. Technical and economical work efficiency have improved. By also taking the dynamic increase in sales profitability into account, one can draw some positive conclusions about the intensive management seen within the dairy sector. Dairies should not only improve their position on the domestic and foreign markets, but also strengthen vertical integration with milk producers.
\end{abstract}

Keywords: dairy industry, efficiency, changes, milk market JEL codes: D24, L10, L66, P10, Q13

\section{INTRODUCTION}

Since the transformation of the economy from socialist to capitalist, significant restructuring processes have taken place in the Polish milk market. In the period 1990-2015, the number of farms involved in milk production decreased by over $85 \%$ (to 265.6 thousand) and the number of dairy cows decreased by half (to 2.4 million head). Conversely, because of the systematic increase in average milk yield by over $71 \%$ (to 5.4 thousand litres), milk production in the country dropped by only $16.4 \%$ (to 12.9 billion litres). Since Poland's accession to the EU, however, milk production in the country has grown steadily, albeit limited by the milk quota system operating until 2015. The level of milk quota negotiated with the EU by Poland constituted 2/3 of the postulated level.
Therefore, virtually immediately after joining the $\mathrm{EU}$, attention was paid to the necessity to increase the insufficient milk quota granted (Smoleński, 2007). This was essential because it did not allow the full use of production and processing potential. In addition, it diminished the price and cost advantages of the Polish dairy industry (Szajner, 2009). The scale of farm milk production has grown. The average herd of cows grew in this period from 2.7 to 9.2 head, and, currently, almost $28 \%$ of the 265.6 thousand farms have more than 10 milk cows - i.e. over $76 \%$ of the 2.4 million dairy cows, in contrast to 20 years earlier when this represented just $1.7 \%$ of the 1,309 thousand farms and $14.7 \%$ of a total of 3.4 million dairy cows (GUS, 2016). What is more, significant changes occurred in the allocation of the volume of produced raw material to increase sales, including deliveries to

${ }^{1}$ Corresponding author: Racławickie 14, 20-950 Lublin, Poland, maria.zuba@kul.pl, +48 814453433 
dairies. The share of milk produced for sale increased by almost 27 p.p. to $82.1 \%$. Such changes in milk production significantly affected the restructuring process of the dairy industry. In addition, agricultural cooperatives, including those dealing with dairies, entered the period of economic transformation as a developed sector, with significant organizational, membership and economic potential. In the new system, a plan was conceived to restore the cooperatives to operating within their original mandate in accordance with the theory of cooperative movement - i.e. one that stressed self-reliance, self-governance, selffinancing - the so-called 3-S. According to the idea of the cooperative movement, of paramount value are the interests of the cooperative members-farmers and co-owners (MacDonald and McBride, 2010) and there was a desire to return to this. The intention was to purge the cooperative movement from the distortions of socialist artifice and give co-operatives a character consistent with the goals and mechanisms of the market economy. However, there was a collapse of cooperatives as a result, inter alia, of new regulations that were unfavourable for the industry (Piekara, 2000). The objective of this work is to analyse structural changes in Poland's dairy industry and assess their impact on the efficiency of dairies.

\section{THEORETICAL BACKGROUND}

Representatives of the industry's economics are not in agreement as to how the industry should be defined. Based on the theory of the structure of the industry, it is assumed that the companies that produce the same products are grouped in the same industry. According to A. Marshall, the same industry includes companies manufacturing products with the same technical characteristics. Thus, the supply side of the economy formed the crux of the consideration. Nevertheless, goods can be substitutes for one another and the same products can be produced using different technologies. The concepts of E.H. Chamberlin, J. Robinson, A. von Stackelberg, L. Abbott, J.S. Bain, and M.E. Porter were different from those of A. Marshall. They emphasized the demand side of the economy. They took the possibilities of substitution between goods into account and drew attention to customer needs
(Gorynia et al., 2000). The entire industry influences its participants through its characteristics. These are features that can be attributed to enterprises such as efficiency, profitability and structure-organization of the industry from perfect competition to monopoly, degree of concentration, life cycle, existence of strategic groups, industry entry and exit barriers, existence of balance or imbalance on the respective industry market (Gorynia, 1995). The basic research trends in the theory of industry include neoclassical theory, the Austrian school trend, behavioural theories, managerial theories, new institutional economics and the evolutionary theory of the industry. In the neoclassical theory, the basis is the general equilibrium model referring to the situation of the perfect market. The main core of the theories originating from the Austrian school is the conviction of continuous variability of the economic system, which is why studies of various types of competitive processes are very popular within this school. The distinctive feature of the behavioural trend is the vision of a company made up of many individuals with diverse, opposing goals, making decisions in conditions of uncertainty and characterized by limited rationality. The managerial theories perceive the company as a coalition of various interest groups with conflicting goals. The new institutional economy includes, among others the theory of transaction costs, agency theory, theory of property rights. In evolutionary economics, the foundations refer to the theory of Schumpeter, treating innovation as the main driving force behind the processes in the industry (Gorynia et al., 2000).

If the industry is identified with, for example, a group of companies offering substitutes then they are certainly competing companies, and thus interacting with each other through the use of competitive strategies. Two basic types of interactions between industry players are competitive struggle and cooperation. The structure and concentration in the industry shape the intensity of competitive and cooperative processes in the industry. The number and strength of individual entities forming the industry determine the price decisions of individual enterprises (Jankowska, 2002). Within the framework of the Chicago school there is a model based on the efficient structure hypothesis (ESH). This determines the positive impact 
of the concentration on the results of enterprises. In contrast to the Harvard school, there is another explanation for this phenomenon. According to the ESH theory, the more effective companies have greater market power and therefore achieve higher profits (Kraciuk, 2008).

The change of the economic and political system in Poland in 1989 led to the emergence of the phenomenon of competition. The main direction of development on the competitive market for the dairy industry in the country is its concentration. The concentration process in milk processing was already postulated by experts over 20 years ago. It was pointed out that it had taken place in other European countries between 1950 and 1970, bringing positive results. The benefits of concentration concern the production, organizational, financial, marketing and distribution spheres of the dairy (Zalewski, 2000). The experience of many countries indicates, however, that the concentration of processing cannot be made quickly if there is a lack of capital, infrastructure and an appropriate scale of milk production (Sznajder, 1999).

\section{MATERIALS AND METHODS}

This work uses data from the Institute of Agricultural and Food Economics-National Research Institute (IAFE-NRI) as presented for individual years in the Milk Market magazine. Moreover, it utilizes Central Statistical Office (CSO) data. In addition, data on the largest dairies in Poland from their websites were used.

The net return on sales ratio (ROS) was employed to analyse the efficiency of the dairy. As the most synthetic indicator of sales profitability, this covers the result of the entirety of an industry's operations as expressed in net result (net profit) and sales revenues (Bednarski, 1997). Other indicators used in assessing the efficiency of management in the dairy industry are the figures for technical labour productivity and economic labour productivity. The classic index of labour productivity - i.e. work efficiency - reveals production per hour of work (Hall and Taylor, 2000). The article proposes to assess the statistical efficiency of the employee via the amount of work done (in the case of the dairy industry, it will be expressed as volume of processed milk produced) and in the development of sales revenues.

$$
\begin{gathered}
\text { Technical labour productivity }(T L P)= \\
=\frac{\text { Amount of processed milk }}{\text { Number of employees }} \\
\text { Economical labour productivity }(\text { ELP })= \\
=\frac{\text { Sales revenues }}{\text { Number of employees }}
\end{gathered}
$$

Research into Poland's dairy industry (dairy cooperatives) confirms the positive impact of the dairy operation scale and work efficiency on the financial outcome (Pietrzak, 2006). Intensive management is based on achieving revenue and profit growth through effective technical and organizational progress (Bednarski, 1997). A simplified investment rate (I) was used to assess the degree of investment. It is the relation of the value of capital expenditures, the purpose of which is primarily to create new fixed assets or to improve the existing, to the value of depreciation - i.e. the cost related to gradual wear of fixed and intangible assets (Dróżdż, 2016). The concentration ratio $(\mathrm{CR})$ indicator was used as the basic indicator of market concentration, showing the percentage share of the largest suppliers in the selected category that characterizes the market (Kraciuk, 2008).

\section{RESULTS AND DISCUSSION}

In 1990, cooperatives were the only entities on the milk market, although after a few years they constituted $90 \%$ of all entities in the dairy industry and held a $86 \%$ share in milk purchases. Furthermore, as the decade unfolded, employment was significantly reduced by $30 \%$ to over 56 thousand people (Table 1). The new act of 1990 on cooperatives deprived them, by liquidation of hitherto existing cooperative unions and the prohibition of creating new ones, of support in terms of organizational, economic and legal counselling, professional auditing, their own press and centres of personnel improvement. This led to errors in the cooperative's activity. In turn, helplessness 
brought about limitation of activity and loss or sale of assets for current needs (Boczar, Szelążek and Wala, 1993). In addition, dairy co-operatives no longer received state subsidies, so they did not have any current assets. The aforementioned, allied with high inflation and a high interest rate on loans, created an extremely difficult financial situation (Gornowicz, 2003; Brzozowski, 2003; Brodziński, 2005). The cooperative dairy industry's financial health deteriorated until about 1995 as a result of the decrease in the use of processing capacity (down to $50-60 \%$ of the total in 1995). The reasons for the low utilization of production capacity were, among others, that the decrease in real incomes of the population caused a drop in demand for dairy products. There were problems with the availability of raw material (Sarnecki, 2004). Dairy cooperatives lacked their own capital for the modernization of obsolete machine parks which had depreciated, were energy and capital-intensive, thus deepening the technical and technological gap (Zalewski, 2000).

There was a significant decentralization of the milk processing industry (Table 1) as measured by the average milk processing level per dairy (down to about 18 million litres). The reason was a drop in the volume of purchased and processed milk (by $38 \%$ ). The liberalization of the market meant that within two years there were, albeit in the short-term, 70 new dairies, mostly small private entities and companies, which were often organized on the basis of declining cooperatives. In the difficult macroeconomic conditions, unfortunately, the dairies generated negative sales profitability. Since the late 1990s, restructuring processes in the milk processing segment have accelerated significantly. The concentration of milk processing and rationalization of its production structures is evidenced by the decrease in the number of dairies and in the employment figures. The modernization of processing plants also followed, and is indicated by the high investment rate (Table 1).

Dairy companies eventually modernized the milk purchase organization, financed the farmers' purchase of milk cooling and milking equipment, provided milking hygiene consultancy, covered the costs of farmers' cooperation with veterinary surgeons, and applied price bonuses (up to $40 \%$ ) for highest quality of milk. Launching the production of new dairy products, improving the quality of products produced so far, raising veterinary and environmental standards required increased investment. A stimulus for investment growth was created by preferential loans for the restructuring of the dairy sector from the state budget (Seremak-Bulge, 2005). With such investments, Poland's dairy industry perceived the possibility of

Table 1. Changes in milk processing in Poland in selected years

\begin{tabular}{|l|c|c|c|c|c|c|}
\hline Specification & 1990 & 1995 & 2000 & 2005 & 2010 & 2015 \\
\hline Number of dairies & 348 & 336 & 324 & 265 & 205 & 177 \\
\hline Share of entities from the cooperative sector (\%) & 100.00 & 90.18 & 82.41 & 80.75 & 72.68 & 67.80 \\
\hline Share of co-operatives in milk purchase (\%) & 100.00 & 85.90 & 76.42 & 74.88 & 71.26 & 68.66 \\
\hline Number of employees & 80700 & 56300 & 50400 & 39300 & 34870 & 32238 \\
\hline Average milk volume processed by a dairy (million litres) & 28.24 & 18.03 & 20.02 & 31.55 & 42.56 & 59.64 \\
\hline TLP (million litres) & 0.12 & 0.11 & 0.13 & 0.21 & 0.25 & 0.33 \\
\hline Average sales of dairy products by a dairy (USD million) & - & 7.05 & 8.83 & 22.05 & 37.37 & 40.33 \\
\hline ELP (USD million) & - & 0.04 & 0.06 & 0.15 & 0.22 & 0.22 \\
\hline ROS (\%) & - & -0.29 & 0.1 & 1.65 & 2.21 & 1.31 \\
\hline I & - & 2.23 & 1.56 & 1.48 & 1.34 & 1.35 \\
\hline
\end{tabular}

Source: own study based on IAFE-NRI data. 
producing products that would compete with those imported, and began to recognize fully the need to penetrate external markets. Hence, Poland's dairy industry had to adapt their product range to changing consumer preferences. The demand for products with a higher degree of processing, functionality and convenience in packaging increased. In addition, the modernization of plants brought about improvements in the efficiency of their operation. The increase in milk production is considered one of the most important factors leading to a reduction in production costs and the improved competitiveness of milk production and its processing in the Polish market and in that of the EU (Sznajder, 1999; Parzonko, 2013).

Modern machines and equipment have led to, since 1995, an increase in the average amount of milk processed by a typical dairy plant site by a factor of 3.3, while technical performance also increased 3 -fold (Table 1). The reason for such figures was not only a decrease in the number of dairies (by $47 \%$ ) and a reduction in employment (by $43 \%$ ), but also an increase in the volume of raw materials processed by the sector (by $75 \%$ to 10.56 billion litres). But the technical efficiency of dairies in Poland is still 3-4 times lower than in Germany or Sweden and a dozen or so times smaller than in the Netherlands (Zuba-Ciszewska, 2015b). Owing to increase technical productivity, the value of sales in this period also increased dynamically (by USD 4.8 billion to over USD 7 billion), and thus the economic efficiency of dairies and dairy employees was even enhanced to a greater extent than by technical efficiency (more than 5 times). Export sales also had a significant impact on the increase in revenues in milk processing, especially after 2005. Currently, they generate over $15 \%$ of all sales revenues, and their value in 2015 amounted to USD 1.8 billion - i.e. 0.7 billion more than in 2005. By also taking the dynamic increase in sales profitability into account, one can make some positive conclusions about the intensive management seen within the dairy sector. The concentration of milk production in Poland will continue to grow due to the increase in milk production, and is determined by the national increase in demand for dairy products (Adamski and Ziętara, 2014). Research indicates that further processes of concentrating milk processing are necessary due to the high rate of concentration changes in milk production (Kapusta, 2011), and the related technological progress. These provide an opportunity for further development of the dairy sector in the country (Seremak-Bulge, 2013). Very important in this process is intellectual capital, its decides about the efficiency in how dairies use their resources (Zuba-Ciszewska and Kijek, 2016). Further concentration of the industry is also driven because of the increased export opportunities for Polish dairy products (Szajner, 2009). The share of final consumer products (yoghurts, milk beverages, cheese, butter and ice cream) in the export commodity structure in 2016 amounted to $56 \%$, i.e. 20.2 p.p. more than in 2006. In the context of using production resources and processing the scale effects that determine efficiency, further concentration may improve this relatively small proportion of consumer products in the export structure. It is also worth noting that the concentration results in dairies are diversified due to their scale of production and the type of product (Zuba-Ciszewska, 2015b).

In 2015, 241 dairies were involved in the processing of milk in the country, including 177 employing more than 10 people. Cooperatives play an important role in the milk market because they account for almost $61 \%$ of all dairy plants (Sznajder, 2016). There are at least several dairies in each region. However, their clear concentration can be seen in the belt stretching from the south-west to central Poland voivodeships, and further down to the three voivodships in the east of the country (Lublin Voivodship, Podlasie, Warmia and Mazury). Over $88 \%$ of the dairies are located in these 10 regions. Almost all regions with a high number of dairies have a good raw material base (apart from the Silesian and Lesser Poland voivodships). And three of the voivodships (Masovia, Podlasie, Greater Poland) are responsible for almost $55 \%$ of the volume of milk produced in the country. Dairy cooperatives are concentrated in regions with a large or very large overall number of dairy plants. This confirms the crucial role of cooperatives in the Polish dairy industry, strengthened by experience and a longstanding tradition (over one hundred years). Research shows that domestic dairies, especially dairy cooperatives, are still an important link in the regional dairy chain (Zuba-Ciszewska, 2018). They 
form a local food system delivering products mainly to consumers in the country.

An example of the progressive consolidation of the dairy industry are the two largest dairies in the country (Mlekovita Dairy Cooperative and Mlekpol Dairy Cooperative), both based in the Podlasie Voivodship. For more than ten years now, these cooperatives have united in their structure further dairies from various regions of the country, sometimes those experiencing financial problems. They use the existing production potential (such as, for example, specific production lines), invest in a new plant and sometimes limit the product range to increase the size of production. Currently, they have almost 30 plants with over 25 thousand farmers delivering milk. Both dairy cooperatives have a high share in the purchase and processing of milk, which is confirmed by the value of their $\mathrm{CR}_{2}$ index on the milk processing market. For 2004, this index was $18 \%$ and for 2018 it was already $38 \%$. Both entities have a stable source of financing - i.e. a high share of their own equity, while implementing different strategies for its development (Zuba-Ciszewska, 2015a). In central Poland there are several significant dairy groups that have plants in other provinces (LACPOL has 10 plants, POLMLEK 6, and OSM Łowicz 4). Many foreign concerns are withdrawing from the domestic milk market or some of its segments - e.g. in 2016, Danone liquidated its plant in Warsaw, and Zott closed one in Raciborz. Mlekovita bought the Baranów factory from Hochland, Polmlek took over the dairies from the Dutch Friesen in Mława, the Austrian Dr. Oetker in Maków Mazowiecki and from the Danish Arla Foods in Gościn. The market of dairy products in the country is characterized by the phenomenon of consumer ethnocentrism (Grześ, 2014), which turns out to be a market entry barrier. Due to the concentration of the dairy industry by dairy groups, including mainly cooperative ones, the synergy effect is not only improving their competitive position on the market, but also increasing the range of consumer products and strengthening the already strong image of Polish brands of food products among the consumers. For example, SM Mlekovita offers a thousand different dairy products.

Dairies focusing not only on the growth of production, but on the increase of added value provided by highly processed products. Thus, there were significant changes in the production structure, leading to better, more profitable use of the processed material. The production structure witnessed an increased share of ripening rennet cheese, cottage cheese, processed cheese, cream and yogurt, ice cream and milk drinks. This process intensified over time. In the period between 1991-2015, the production of highly processed products grew systematically. The most dynamic was in the production of milk beverages (with an almost 11 -fold increase to 717,000 tonnes), ice cream (9-fold to 265,000 tonnes), processed cheese (over 5-fold to 78 thousand tonnes) and ripening cheeses (almost 3 -fold to 310,000 tonnes). In the case of basic products such as cottage cheese and cream, the increase was also systematic but smaller (2.6 and 2.3 times). Butter production, after a sudden collapse in the early 1990s (by 1/3), among others due to the negative advertising by the margarine industry, finally returned to the level of 25 years previous (191 thousand tonnes) in 2015. Polish dairies, similar to those from other countries, are trying to offer more processed products (MacDonald et al., 2010).

\section{CONCLUSIONS}

The article pointed out that the concentration of milk processing and the rationalization of its production structures has positively influenced the efficiency of dairies. Therefore, it is one of the directions for improving the economic results in this sector. There are two dairy cooperatives on the Polish milk processing market, which have a high and growing share in milk processing. Nevertheless, there is room for further consolidation of the sector, although sometimes it may face barriers of a non-economic nature, such as the management of the dairy being reluctant to lose independence. However, the benefits of increased sales, improved technical and economic performance confirm the justification for structural changes in the dairy industry. Dairies should not only improve their position on the domestic and foreign markets, but also strengthen vertical integration with milk producers supplying raw material often being the co-owners of dairies, as members of the cooperative. 


\section{REFERENCES}

1. Adamski, M., Ziętara, W. (2014). Skala produkcji, efektywność i konkurencyjność polskich gospodarstw wyspecjalizowanych w produkcji mleka [The scale of production, efficiency and competitiveness of Polish farms specialized in milk production]. Zagadnienia Ekonomiki Rolnej, 1, pp. 95-117.

2. Bednarski, L. (1997). Analiza finansowa w przedsiębiorstwie [Financial analysis in the enterprise]. PWE, Warszawa.

3. Boczar, K., Szelążek, T., Wala, F. (1993). Spółdzielczość wiejska w okresie przełomu [Rural cooperatives at the turn]. Fundacja F. Eberta w Polsce, Warszawa.

4. Brodziński, M.G. (2005). Spółdzielczość obsługująca wieś i rolnictwo w okresie przekształceń ustrojowych [Cooperatives serving the village and agriculture during the transformation period]. KRS, Warszawa.

5. Brzozowski, B. (2003). Spółdzielczość wiejska. Wybrane zagadnienia [Rural cooperatives. Selected issues]. Wydawnictwo AR w Krakowie, Kraków.

6. Dróżdż, J. (2014). Ocena sytuacji ekonomiczno-finansowej przemysłu spożywczego w latach 2010-2014 [Assessment of the economic and financial situation of the food industry in 2010-2014]. IERiGŻ-PIB, Warszawa.

7. Gornowicz, M. (2003). Polskie mleczarstwo w aspekcie konkurencyjności na jednolitym rynku UE [Polish dairy industry in terms of competitiveness in the EU single market]. Wydawnictwo Uniwersytetu Warmińsko-Mazurskiego, Olsztyn.

8. Gorynia, M. (1995). Mezoekonomia-modele samoregulacji branży [Mezzoeconomics - models of self-regulation of an industrial branch]. Ekonomista, 5, pp. 815-837.

9. Gorynia, M. et al. (2000). Branża jako przedmiot badań w ekonomii [Industry as a subject of research in economics]. Gospodarka Narodowa, 3, pp. 36-54.

10. Grześ, A. (2014). Zachowania etnocentryczne nabywców na rynku produktów mleczarskich [Customer ethnocentrism on the dairy market]. Marketing i Rynek, 6 , pp. 237-250.

11. GUS (2017). Charakterystyka gospodarstw rolnych 2016 [Characteristics of agricultural holdings 2016]. Dział Wydawnictw Statystycznych, Warszawa.

12. Hall, R.E., Taylor, J.B. (2000). Makroekonomia [Macroeconomics]. PWN, Warszawa.

13. Jankowska, B. (2002). Branża jako mezosystem gospodarczy [Branch as an economic mesosystem]. Ruch Prawniczy, Ekonomiczny i Socjologiczny, 64, pp. 233 $-243$.
14. Kapusta, F. (2011). Konsolidacja mleczarstwa pilną potrzebą [Consolidating dairy products with an urgent need]. Przegląd Mleczarski, 4, p. 44.

15. Kraciuk, J. (2008). Koncentracja produkcji w polskim przemyśle spożywczym [Concentration of production in Polish food industry]. Problemy Rolnictwa Światowego, 15, pp. 33-41.

16. MacDonald, J.M. et al. (2010). Profits, Costs, and the Changing Structure of Dairy Farming. In: Daigle, J.M. (ed.) Transformation of U.S. Animal Agriculture. Nova Science Publishers, New York, p. 76.

17. MacDonald, J.M., McBride, W. (2010). The Transformation of U.S. Livestock Agriculture: Scale, Efficiency and Risks. In: Daigle, J.M. (ed.), Transformation of U.S. Animal Agriculture. Nova Science Publishers, New York, pp. 162-164.

18. Parzonko, A. (2013). Globalne, regionalne i lokalne zróżnicowanie produkcji i przetwórstwa mleka [Global, regional and local diversification of milk production and processing]. Wydawnictwo SGGW, Warszawa.

19. Piekara, A. (2000). Samorządność, samorząd, rozwój [Self-government, self-government, development]. Wydawnictwo UW, Warszawa.

20. Pietrzak, M. (2006). Efektywność finansowa spółdzielni mleczarskich - koncepcja oceny [Financial effectiveness of dairy cooperatives - the concept of evaluation]. Wydawnictwo SGGW, Warszawa.

21. Sarnecki, J. (2004). Przetwórstwo i rynek mleka w Polsce w ujęciu przestrzennym [Processing and milk market in Poland in spatial terms]. IERiGŻ, Warszawa.

22. Seremak-Bulge, J. (2013). Restrukturyzacja produkcji mleka [Restructuring milk production]. Przegląd Mleczarski, 9, p. 40

23. Seremak-Bulge, J. (ed.). (2005). Rozwój rynku mleczarskiego i zmiany jego funkcjonowania w latach 1990-2005 [Development of the dairy market and changes in its functioning in the years 1990-2005]. IERiGŻ-PIB, Warszawa.

24. Smoleński Z. (2007). Wpływ WPR na rynek mleka [The impact of the CAP on the milk market]. In: Gburczyk, S. (ed.) Wpływ WPR na rynki rolno-spożywcze [The impact of the CAP on agri-food markets]. IERiGŻ-PIB, Warszawa, p. 41.

25. Szajner P. (2009). Perspektywy eksportu polskich produktów mleczarskich w zmieniających się uwarunkowaniach [Prospects for the export of Polish dairy products in changing conditions]. IERiGŻ-PIB, Warszawa.

26. Sznajder, M. (1999). Ekonomia mleczarstwa [The economy of dairy industry]. Wydawnictwo AR w Poznaniu, Poznań 
27. Sznajder, M. (ed.) (2016). Atlas Firm Przemysłu Spożywczego 2014/2015 [Atlas of Food Industry in Poland 2014/2015]. Horyzont Mateusz Sznajder, Przeźmierowo.

28. Zalewski, A. (2000). Gospodarka mleczarska a rynek [Dairy economy and the market]. IERiGŻ, Warszawa.

29. Zuba-Ciszewska, M. (2015a). Wpływ koncentracji kapitału własnego na jego efektywność w wybranych spółdzielniach mleczarskich w Polsce w latach 2003-2012 [The influence of the concentration of equity capital on its efficiency in selected milk cooperatives in Poland in years 2003-2012]. Ekonomika i Organizacja Gospodarki Żywnościowej, 109, pp. 107-121.

30. Zuba-Ciszewska, M. (2015b). Struktura mleczarń ze względu na skalę produkcji wybranych produktów mleczarskich w Polsce i Niemczech w latach 2003 2012 [The structure of dairies as regards the scale of production for chosen milk products in Poland and Germany in years 2003-2012]. Problemy Rolnictwa Światowego, 15 (30/1), pp. 161-171.

31. Zuba-Ciszewska, M. (2018). The role of dairy cooperatives in reducing waste of dairy products in the $\mathrm{Lu}$ belskie voivodeship. Journal of Agribusiness and Rural Development, 1 (47), p. 104.

32. Zuba-Ciszewska, M., Kijek, T. (2016). Efektywność wykorzystania kapitału ludzkiego w największych spółdzielniach mleczarskich w Polsce [The efficiency of human capital use in the largest diary cooperatives in Poland]. Marketing i Rynek, 3, pp. 1109-1120. 